\title{
Surfaces
}

\section{LITERATURE, LOCALISM, AND LOVE}

\section{Bruce Robbins}

Volume 4, 1994

URI : https://id.erudit.org/iderudit/1064951ar

DOI : https://doi.org/10.7202/1064951ar

Aller au sommaire du numéro

\section{Éditeur(s)}

Les Presses de l’Université de Montréal

ISSN

1188-2492 (imprimé)

1200-5320 (numérique)

Découvrir la revue

Citer cet article

Robbins, B. (1994). LITERATURE, LOCALISM, AND LOVE. Surfaces, 4. https://doi.org/10.7202/1064951ar

\section{Résumé de l'article}

Avec un humour dévastateur, l'auteur tente de contrecarrer une tendence actuelle en critique littéraire qui consiste à faire voir et à promouvoir l'interprétation textuelle comme un acte d'amour, une pratique purement détachée de tout intérêt politique. L'auteur prélève chez Stanley Fish, Elaine Marks et John Guillory les trois remarques de type new localist autour desquelles il élabore son propos.
Ce document est protégé par la loi sur le droit d'auteur. L'utilisation des services d'Érudit (y compris la reproduction) est assujettie à sa politique d'utilisation que vous pouvez consulter en ligne.

https://apropos.erudit.org/fr/usagers/politique-dutilisation/ 


\title{
LITERATURE, LOCALISM, AND LOVE
}

\author{
Bruce Robbins
}

\begin{abstract}
Avec un humour dévastateur, l'auteur tente de contrecarrer une tendence actuelle en critique littéraire qui consiste à faire voir et à promouvoir l'interprétation textuelle comme un acte d'amour, une pratique purement détachée de tout intérêt politique. L'auteur prélève chez Stanley Fish, Elaine Marks et John Guillory les trois remarques de type new localist autour desquelles il élabore son propos.
\end{abstract}

\section{RÉSUMÉ}

With devastating wit, the author attempts to nip in the bud a new tendency in literary criticism which consists in promoting the practice of interpretation as a purely disinterested, unpolitical, act of love. The article is woven around three instances of new localist rhetoric in recent works by Stanley Fish, Elaine Marks and John Guillory.

This essay finds an epigraph in an article published by the London Review of Books in 1993 wherein Stanley Fish points out that "Human beings are always in a particular place... they cannot be in more than one place, at least not at the same time" ("Why Literary Criticism is like a Virtue"). Echoing the views currently held by a number of other distinguished critics, Fish argues here in favor of what may be called a new localism: a return to the practice of literary criticism in and for itself, i.e., divested of the political concerns associated with, for exemple, cultural studies. The political or cultural studies approach, in his opinion, is founded upon the mistaken 
belief that "if you want to know what is really going on in literature, look elsewhere" (11).

The argument may be summed up as follows. Figuring out "which interpretation of a poem will contribute to the toppling of patriarchy or to the war effort" is absolutely distinct from figuring out "what a poem means," for each option occupies a distinct place. It is as clear that a poem does mean something on its own as it is clear that a given object does occupy a particular place. Since two objects cannot occupy the same space at the same time, politics can only come from somewhere else, and if so, it belongs somewhere else. Consequently, Fish recommends that we let the politicotheoretical express go thundering by into the distance and content ourselves with a modest ride on the literary local.

Coming from so astute a critic as Fish, this identification of location with true identity cannot, I believe, be taken at face value. Indeed, it seems difficult to imagine his plea as an invitation to rehearse twenty-year old arguments about how texts aren't bounded and finite or about how criticism cannot simply restore them to themselves. Rather than objecting, then, that there is no way of separating off "what a poem means" from the uses to which it is put; rather than suggesting that in the London Review of Books Fish himself is using Milton for the public purpose of re-legitimizing criticism, rather than proposing (as I have just spent a whole book trying to do) that legitimation talk like his forms some part of all critical performances, even in less public publications -- in short, rather than be tiresome and predictable, I want to try to be practical, and to address what I take to be the motives and effects of this new localism.

If it is not a meaningless twist of fashion, the new localism would seem to be a tactical or pragmatic move in the continuing culture wars, an attempt to pacify criticism's most strident enemies by retreating out of the glare of unfriendly publicity focussed on "theory," "cultural studies," and "PC" and returning to our assigned seat, where we will once again look studious and inoffensive if also a bit irrelevant.[1] Some sort of reflex, discipline-wide survival instinct might also help explain why the "post-theory" mood seems to consolidate feelings shared by otherwise quite divergent critics. In the Chronicle piece of two weeks ago, "Scholars Mark the Beginning of the Age of 'Post-Theory,'" the crucial question is "whether literary criticism has become too unliterary" (A 17), that is, whether literary criticism still exists as such.[2] The author doesn't even bother to distinguish between a retreat from theory (signalled by the catch-phrase "post-theory") and a retreat from politics (note the absence of a catch-phrase "post-politics"). It is as if any and all potentially divisive questions about the ends or uses of literary interpretation had to be lumped together and deferred together in the common interest of ensuring the survival of literary interpretation. 
Now one cannot argue with the survival instinct. If this is a matter of disciplinary survival, then of course arguing about how identities are not like places (and, according to geography, neither are places) will seem badlytimed quibbling, if not worse. In that case, John Guillory's parallel with the case of the Mapplethorpe photos would be apposite: we need a clearly delimited category of the aesthetic, Guillory suggests, in order to protect those photographs, just as we need one in order to protect ourselves, because otherwise the small social space in which those photographs can be exhibited, and in which we work, will be squeezed shut by censorious pressure from the Right. On the other hand, if we decided that -- withdrawal of funds and pressure to increase classroom hours notwithstanding -- this was not a matter of immediate institutional life-and-death, then the panicked rush toward the local track might look like an over-reaction, or even like what has been called survivalism: an enthusiastic anticipation of apocalypse encouraging and camouflaging an unrestrained regression to more primitive social forms.

I am inclined to feel that the threat posed to cultural criticism by bad publicity is not really deadly. And perhaps for the same reason, I'm also inclined to suspect that collective survival is not the real or primary goal of the new localism. Consider the way the new localists have appealed to a lexicon of sensuality and eroticism. As he approaches the climax of his argument, Stanley Fish, for example, explains his title as follows: "literary interpretation, like virtue, is its own reward. I do it," he says provocatively, "because I like the way I feel when I'm doing it." Among many other allusions to liking and feeling that have suddenly cropped up in new localist prose -- a move from bad publicity to what I think of as bad privacy -- I will cite only Elaine Marks's piece in the last MLA Newsletter. Complaining about "the deadly weight imposed on literary texts by the insistence on 'relevant' moral and social issues", Marks writes as follows: "I must confess that what continues to stir my imagination and even to turn me on..." is literary masterpieces. "I came into our profession through a passionate curiosity about and love for a modern language and literature... This curiosity and this love have not faded."[3]/pp. 7-8/

There is no need to doubt the genuineness of the passion thus displayed in order to be a bit uncomfortable with the meaning of the display itself. The rhetoric of confession at first seems timid, as if (like literature itself in one of its better known definitions) it dared to affirm nothing at all beyond the truth of its own feelings. But it is better described, I think, as passive/ aggressive, for the apparent timidity (this is only what $I$ feel) protects from reasoned argument assertions that have a hidden sting, that are rather violently combative. To pitch our legitimation talk at the level of love is to embrace with equal indulgence any number of objects: he loves collecting stamps, she loves collecting automatic rifles, I love literature. But to talk of love is also to make an invidious differentiation of subjects. Like displaying an American flag on my bumper, displaying my love for literature implies that unnamed others do not love literature, or do not love it passionately or faithfully enough. To return to my earlier metaphor, these unnamed others -- 
or these political critics -- are not proud enough of their locality: their libidos have wandered, they are promiscuous cosmopolitans who will not stay home where they belong. It is as if we were offered the following parody of a syllogism: I love literature, and there's no denying the authenticity of my feelings on this matter; I love literature, and that's how I got into this business; I love literature, and there's no denying that the true essence of this business is what provokes and nourishes my unarguable feelings: literary criticism is what I love to do. Literary criticism: love it (love what I loved when I first entered it), or leave it.

I myself do not love the nativist, Moral Majority tone of this, with its strong suggestion that the political is the adulterated, an unfaithful criticism, a sort of adultery. But I am not speaking simply in the name of a certain politics, or even of political criticism in general. Nor am I always and everywhere against the offering of feelings as evidence, or against acknowledging how much feelings have to do with our profession. On the contrary. It is almost inevitable to find the vocabulary of eroticism when any critic, like Elaine Marks, tries to describe an initial attraction to the discipline. Disciplines, as Pierre Bourdieu has argued, seek to reproduce themselves, and the process of reproduction, in disciplines as in couples, requires the mobilizing of libidinal energy. The moment of greatest libidinal drama for a discipline, its equivalent to the adventure of sexual bonding that structures so many novels, is the moment of recruitment -- the moment when a member of the public is picked out and drawn into the disciplinary community. From the point of view of the recruit, a moment that has something in common with "falling in love." And all the more so to the extent that disciplinary or professional communities, dispersed geographically in networks across the nation and even across the world, take over some of the emotional functions of families and residential communities, which are more localized.[4]

The problem is not the intensity of the feelings, then, but whose feelings matter and whose don't, or rather the effect that Elaine Marks's display of feeling is likely to have on those who do not have the flag on their bumper, or a car to display their feelings on. I'm referring, first and most obviously, to students, both undergraduate and graduate, who are one immediate public of criticism, the pool from which its potential recruits will or will not emerge. Many of these students have strong feelings about the projects of cultural studies, theory, politics. Their libidinal energies have been engaged by the work of people who are present here today, along with that of charismatic names like Michel Foucault and Jacques Derrida, Edward Said, Donna Haraway, Gayatri Spivak, Judith Butler, Cornel West, Paul Gilroy, James Clifford, and so on. They have been "turned on" by what these people do or invite us to do with literature, and also by what they do and invite us to do with cultural fields and issues that are not literature, but that matter a great deal to our culture all the same -- texts that have swum into our ken both because of the spilling over of literariness into other domains, like Orientalism and AIDS discourse, and because newly represented groups have found their concerns represented in such domains. Whether or not they are members of a minority, these students almost certainly have some 
libidinal investment in the project of democratizing cultural representation -a project which in no way contradicts an extremely selective quest for objects, past and present, that are worthy of the highest reverence.

Seen against this background, literary localism should not look so ethically attractive after all. It should look more like a fall-back position: what you say to outsiders about what you're doing when you are scaling back your claims on the public's attention, when you have risen high enough to afford the luxury of being left alone, when you don't really care very much what happens to the ambitions of the next generation. I am not just complaining that displays of feeling like Elaine Marks's "exclude" (as the saying goes) the feelings of others, or that "confessions" like hers, on the part of people well established in the profession and who have been associated with change in the not so distant past, will have a dampening effect on those who are just entering the profession, or deciding whether or not to enter it. I am afraid that the new localism, the retreat to "literature itself," ignores both criticism's task of public legitimation and its equally public business of recruitment and reproduction. But I would prefer to put the point another way. To demand that the younger generation share the remembered loves of our own professional apprenticeships, how the first time was for us, is to give up on trying to seduce. When the new localism does this retrospection while at the same time withdrawing from any more recent theoretical and political cathexes, the effect is like a cold shower. For all its erotic vocabulary, talk like this isn't sexy.

I want to conclude with one more example of this new localism, an especially intelligent and, I think, an especially dangerous one. In his book Cultural Capital John Guillory offers an indirect defense of the category of literature that passes not through confession, but through an attack on the attackers of the canon. The attack on the canon, which has expanded and finally exploded the category of literature, has been politically misguided, Guillory says, because there are no real political stakes one way or the other in the content of the canon. Following Bourdieu, Guillory suggests that whatever gets taught will serve equally well as "cultural capital," that is, as a possession that will distinguish its possessors from the great unwashed. The real political issue is not the content of education but unequal access to education. If women and minorities have insisted, on the contrary, on obtaining representation in the canon, the working class notably and correctly has not -- first, because it has no "cultural identity" it wants to affirm (its only identity is its poverty, which it would gladly surrender), and second because what it really wants is not to change what is taught but to have access to what is taught. The attack on the canon, then, in Guillory's Bourdieu-influenced class analysis, seems to come not from the working class but from an unholy alliance between women and minorities, on the one hand, and the professional/managerial class, on the other, which has decided that literature is no longer useful. I quote: "The professional-managerial class has made the correct assessment that, so far as its future profit is concerned, the reading of great works is not worth the investment of very 
much time or money. The perceived devaluation of the humanities curriculum is in reality a decline in its market value" (46).

As I say, this is a relatively circuitous case for a return to literature, a case which combines the positive desire of the working class for what others consider valuable knowledge, on the one hand, and on the other, our presumed desire to refuse the new indifference to literature on the part of the new technocratic managers. Like the right-wing defenders of the canon, Guillory spends little time specifying its former value or values, though he does speculate interestingly on what the aesthetic might yet come to mean under dramatically improved social conditions.[5] But under the unimproved conditions of the present, one must still ask what if anything is accomplished by retreating to an older conception of the canon. What is it about the locale of literature that provokes Guillory's nostalgia for it?

When Guillory argues that literature is losing out because it is no longer useful to the bourgeoisie -- that it is "increasingly marginal to the social function of the present educational system" (x) -- he implies that once it was useful, that it once had a "social function." This seems to contradict Guillory's other argument, borrowed from Bourdieu, that the real social function of education is to legitimate the hierarchical division between the classes, a function that does not depend on educational content but only on who possesses it and who doesn't. In support of this argument, it is clear for example that knowledge of Latin and Greek served the ruling class to mark its difference from those below it; it is much less clear that this knowledge contributed in any practical way to their ability to rule. Nor is it clear that the transition from classical to vernacular languages and then from the old criterion of "quality" writing to the new criterion of "creative, imaginative" writing -- that is, to "literature" - -- was ever highly functional. The same doubt undermines Guillory's suggestion that the switch from "literature" to "cultural studies," or from a narrower to a broader canon, is coming about because it will somehow swell the technocratic powers of the professional/ managerial class.

The source of this contradiction -- that the literary content of education matters, and that it doesn't -- is, I think, a version of the (unsexy) localism encountered above. When Guillory follows Bourdieu, he accepts, along with the arbitrariness of cultural capital, the notion that bourgeois or professional/managerial educators like ourselves act out of local professional self-interest so as to reproduce the class hierarchy from which we benefit. Pleased as I am to see Guillory introduce class into the canon debate, I have to say that this conception of class is an analytic disaster. For Bourdieu, though not for Marx or Gramsci, class is a static sociological category, a mere set of income brackets, a fixed and isolated locale on the social map. It allows for no active relationship between classes, no pressure from below, no hegemonic concession from above, no dynamic of articulation whereby fractions of different classes enter into and fall out of alliance with 
each other. Given these assumptions, neither Bourdieu nor Guillory can afford to see that professionals and non-professionals might ever have common rather than merely local interests. And, even more strangely, the real if qualified progressiveness of "literature" as curricular content becomes invisible, even to a defender like Guillory who announces that it is "time for progressive teachers to take back the humanities curriculum -- all of it - -- as an integrated program of study" (50-51).

This is why Guillory has so much less to say in favor of literature than one might expect. It is why he engages only so briefly with the argument of Raymond Williams' Culture and Society -- one of the most seductive pieces of recruiting material that literary criticism has ever produced -- to the effect that the emergent category of "literature" could fulfil both socially functional and socially critical purposes at the same time. And it is why there is so little seduction in Guillory's otherwise beautifully written book. If the content of the canon doesn't matter -- a point Guillory seems to insist on most when he is arguing against the claims of women and minorities to greater literary representation -- if one should properly be indifferent to the success or failure of efforts from below to refashion it, then the most heavily libidinized circuits linking criticism to its various publics will be blocked, and criticism will become local in the most sadly dispassionate sense.

The argument that efforts to change the canon are misguided is of a piece with the argument that the real politics that should concern us lie outside literature, at the level of the academic institutions as bestowers of credentials. Unfortunately, right or wrong, that is a level we have little purchase over -- which is why both the left and the right can so safely strike dramatic postures over it. And, as a consequence, injunctions against any action except at that level degenerate into calls for inaction. What better argument for retiring into the local than an exaggeratedly apocalyptic vision of the global? In fact, Guillory's courageous confrontation with these ultimate limits of the critical enterprise -- a confrontation which gives Guillory's book its strongest erotic charge -- serves his argument primarily as a distraction. If access to a university education were to be fully democratized, would the result be a massive redistribution of cultural capital? Would the canon remain a source or counter for cultural capital if it no longer marked a line of demarcation between haves and have nots? Or would we simply have to start over from scratch, asking an entirely different set of political questions?

In the prolonged meantime, then, there seems to be no reason to give up on projects of less than full democratization that are already redistributing cultural capital. The emotions invested in identity politics may not be as disciplinarily segregated as "love of literature," but they are certainly just as intellectually productive for cultural criticism, and just as capable of nuance. The interdisciplinarity encouraged by theory's expansive literariness has sometimes been intellectually sloppy, but it is too late to rechannel it back 
between the banks of a discrete discipline. In the essay, Jacques Derrida is quoted as follows: "I would urge that we not dissolve into a vague, global interdisciplinarity. We have to ask, What is geography or what is literature?" (A17). Here I will make my own confession: I can think of many questions I would rather hear the answer to. When literary criticism misunderstands its own geography, or thinks it can retreat behind known borders into an autonomous, bounded locality, it is time to learn from geography that the local is not the foundational. Is there anything more boring than looking into our heart in order to write? If we are in search of the disciplinary unconscious, our reasons for coming on board in the first place, the deep sources of an erotic attraction that hold both for ourselves and for our students, we are more likely to find them not underneath, but at its margins, its many points of intersection with other areas of thought and feeling. Now that we've gained some momentum, it is not the time to put on the brakes. No stops are necessary where no one is getting on, or where no one is getting off.

\section{Bruce Robbins}

\section{Dept of English}

\section{Rutgers University}

New Brunswick, NJ 08903

BROBBINS@ zodiac.rutgers.edu

\section{Surface Page d'Acceuil/Home Page}

[1] At a time when the metaphorics of expansionism arouse suspicion and when imperialism is largely understood in a metaphorical sense, it is not hard even for literary critics to see why other disciplines might accuse us of disciplinary imperialism. In this context, stepping back from positions like "everything is literature" might acquire a new ethical attractiveness.

[2] Karen J. Winkler, "Scholars Mark the Beginning of the Age of 'PostTheory,'" The Chronicle of Higher Education (October 13, 1993): A9-17.

[3] Elaine Marks, "In Defense of Modern Languages and Literatures, Masterpieces, Nihilism, and Dead European Writers", MLA Newsletter, (Fall 1993): 2-3. Note the double irony that anti-totalizing theory, with its praise of the local, here turns back against itself, as well as the way the new 
authority of autobiographical feeling and confession is here mobilized against the innovations that made it possible.

[4] The religious vocabulary of vocation and conversion, what Evan Watkins in Work Time cynically calls "mission-talk"-- but then goes on to talk himself-- seems both an embarrassment and a necessity because it tries, as well as it can, to cover or warm this liminal moment. It is at such moments, that is, that the professional community, which more or less successfully suppresses the erotic from its day-to-day functioning-- sexual harrassment obviously names one limit of this success-- must also appeal to the erotic.

[5] John Guillory, Cultural Capital: The Problem of Literary canon Formation (Chicago: University of Chicago Press, 1993). I agree entirely with Guillory's statement that "the specificity of aesthetic judgment is not on this view simply an illusion to be exploded, but rather a privileged site for reimagining the relation between the cultural and the economic in social life" (xiv). 